PRZEGLĄD NAUK HISTORYCZNYCH 2016, R. XV, NR 2

http://dx.doi.org/10.18778/1644-857X.15.02.06

WiTOLD FILIPCZAK

UNIWERSYTET ŁÓDZKI

\title{
Ziemskie urzędy sądowe w życiu politycznym województwa sandomierskiego w latach 1777-1783
}

Streszczenie. W początkowej części artykułu przypomniane zostały obowiązujące w Rzeczypospolitej zasady elekcyjności kandydatów na urzędy sądowe, $z$ uwzględnieniem zmian, jakie $\mathrm{w}$ tym zakresie zachodziły. W badanym okresie w województwie sandomierskim istniały trzy sądy ziemskie, sześć starostw grodowych, ale tylko jeden urząd podkomorzego. W latach 1777-1783 zebrało się siedem sejmików w Opatowie i jeden w Radomiu, które wybrały kandydatów na sandomierskie i radomski urzędy sądowe. W $1783 \mathrm{r}$. prawdopodobnie trzy razy obradowały sejmiki w Stężycy (dla powiatu stężyckiego), jednak ich uchwały nie sa znane. W artykule omówione zostały przygotowania do poszczególnych sejmików, ich przebieg oraz podjęte decyzje. W latach 1777-1778 w Opatowie dokonano elekcji, dyskusyjnych $z$ prawnego punktu widzenia, które wynikały $z$ uznania za wakujacy urzędu sędziego ziemskiego sandomierskiego. Po I rozbiorze jego dotychczasowy posiadacz nie miał już dóbr w pomniejszonych granicach województwa, a ponadto pełnił obowiązki sędziowskie na terenach zajętych przez Austrię. W 1782 r. powstał projekt, zaakceptowany przez króla Stanisława Augusta, powołania trzech urzędów podkomorzego na miejsce jednego, dotychczas istniejącego. Na burzliwym sejmie w 1782 r. nie było możliwości przyjęcia ustawy w tej sprawie. W następnym roku król wycofał się z propozycji, zapewne ze względu na postawę polityczną większości posłów sandomierskich na ostatnim sejmie. Zgodnie $z$ zaleceniem królewskim dokonano więc w Opatowie (w 1783 r.) elekcji kandydatów na urząd podkomorzego całego województwa.

Słowa kluczowe: województwo sandomierskie, ziemskie urzędy sądowe, sejmiki, parlamentaryzm.

\footnotetext{
* Wydział Filozoficzno-Historyczny, Instytut Historii, Katedra Historii Nowożytnej.
} 
$1 \begin{aligned} & \text { owiąc o roli ziemskich urzędów sądowych w życiu politycz- } \\ & \text { nym województw, ziem i powiatów, należy zwrócić uwage } \\ & \text { na dwa zagadnienia. Pierwszym jest rywalizacja o wpływy }\end{aligned}$ związana $z$ obradami sejmików elekcyjnych, na których wybierano kandydatów na ziemskie urzędy sądowe. Drugim jest znaczenie tychże urzędów w lokalnym życiu politycznym, co jest jednak tematem zbyt szerokim, bym mógł go uwzględnić w tym tekście. Oba zagadnienia były ściśle ze sobą związane, gdyż zabiegi o wspomniane urzędy $\mathrm{w}$ znacznym stopniu wiązały się $z$ pozycją, jaka dawały w wojewódzkich lub powiatowych elitach władzy. Mogły istnieć także inne motywy, np. traktujace je jako źródła dodatkowych dochodów, to jednak nie wchodzi w zakres moich zainteresowań.

Swoje rozważania chciałbym zaczać od krótkiego przypomnienia zasad elekcyjności obowiązujących w odniesieniu do ziemskich urzędów sądowych. W Polsce zasada, że szlachta wybiera czterech kandydatów na członków sądu ziemskiego (sędziego ziemskiego, podsędka, pisarza ziemskiego) oraz podkomorzego, miała korzenie średniowieczne. Wzory koronne były wprowadzane także na obszarach wcielanych w XV i XVI w. (odrębne zasady istniały w Prusach Królewskich) ${ }^{1}$.

Na Litwie elekcyjność urzędników tworzących ziemstwo została wprowadzona w wyniku reform Zygmunta Augusta $z$ lat 1564-1566, których ukoronowaniem był II Statut Litewski². W stosunku do podkomorzych zasadę, że król powołuje jednego $z$ czterech kandydatów wybranych przez szlachtę, wprowadzono w 1588 r. ${ }^{3}$ Warto też przypomnieć, że w Wielkim Księstwie wybieralność dotyczyła nie tylko urzędników sądowych. III Statut rozciagnął ją także na chorążych (na Żmudzi od 1629 r.), a ustawy z 1631 (która nie została w pełni wprowadzona w życie) i 1669 r. przewidywały również wybór

${ }^{1}$ A. Swieżaws ki, Rawskie Księstwo Piastów Mazowieckich 1313-1462. Dzieje polityczne, Łódź 1975, s. 165; A. Moniuszko, Mazowieckie sady ziemskie (1588-1648). Organizacja - funkcjonowanie - postepowanie, Warszawa 2013, s. 127-129. Na temat elekcyjności urzędów sądowych w Prusach Królewskich por. S. Achremczyk, Reprezentacja stanowa Prus Królewskich w latach 1696-1772, Olsztyn 1981, s. 82 .

${ }^{2}$ G. Bła s zczyk, Litwa na przełomie średniowiecza i nowożytności 1491-1569, Poznań 2002, s. 120-121.

${ }^{3}$ A.B. Zakrzewski, Wielkie Księstwo Litewskie (XVI-XVIII w.). Prawo- ustrój - społeczeństwo, Warszawa 2013, s. 187; D. Ko n i e czna, Ustrój i funkcjonowanie sejmików elekcyjnych $w$ powiecie brzeskolitewskim do 1764 roku, [w:] Po unii - sejmiki szlacheckie $w$ Rzeczypospolitej XVI-XVIII wieku, red. H. Lulewicz, M. Wagner, Siedlce 2013, s. 43. 
kandydatów na marszałków powiatowych. Na Litwie elekcyjne były nawet niektóre urzędy senatorskie: starosty żmudzkiego (odpowiednika wojewody na tym obszarze) oraz wojewodów połockiego i witebskiego ${ }^{4}$. W XVII w. pojawiła się zasada, że sejmiki litewskie wybierały wprawdzie czterech kandydatów na urzędy, lecz czasami (choć nie zawsze) trzech $z$ nich rezygnowało $z$ ubiegania się o godność. W takiej sytuacji monarcha miał już tylko jedną osobę, której mógł powierzyć wakans ${ }^{5}$.

W 1764 r. na sejmie konwokacyjnym zreformowano sądownictwo ziemskie na Litwie. Zlikwidowano urząd podsędka, a liczbę sędziów ziemskich zwiększono do czterech. Od tego czasu litewskie sejmiki elekcyjne miały wybierać już nie czterech kandydatów, lecz jednego, który musiał jednak uzyskać przywilej królewski ${ }^{6}$.

Do zwoływania zgromadzenia elekcyjnego uprawniony był pierwszy urzędnik w hierarchii, $z$ reguły więc wojewoda (w ziemi dobrzyńskiej kasztelan ${ }^{7}$, na Żmudzi starosta), przy czym na Litwie mógł to zrobić monarcha, o ile przebywał w Wielkim Księstwie ${ }^{8}$. Sejm konwokacyjny z 1764 r. wprowadził zasadę większości głosów na sejmikach elekcyjnych w Polsce ${ }^{9}$, a koronacyjny $z$ tego roku przywrócił ją na Litwie (formalnie obowiązywała od roku 1613) ${ }^{10}$. Na sejmie konwokacyjnym postanowiono, że gdyby wojewoda lub kasztelan nie wydał uniwersału na sejmiki electionis w sytuacji wakatu na ziemskim urzędzie sądowym, szlachta powinna dokonać wyboru

\footnotetext{
${ }^{4}$ A. Rachuba, Wielkie Ksiesstwo litewskie $w$ systemie parlamentarnym Rzeczypospolitej w latach 1569-1763, Warszawa 2002, s. 203.

${ }^{5}$ A.B. Zakrzew s ki, Sejmiki Wielkiego Księstwa Litewskiego XVI-XVIII w. Ustrój i funkcjonowanie: sejmik trocki, Warszawa 2000, s. 162-164.

6 Volumina Legum [dalej: Vol. leg.], t. VII, wyd. J. Ohryzko, Petersburg 1860, s. 88-89 (ustawa: Sady ziemskie); A.B. Zakrzewski, Sejmiki Wielkiego Księstwa Litewskiego epoki stanisławowskiej (do 1788 r.). Zmiany w ustroju i funkcjonowaniu, [w:] Ziemie północne Rzeczypospolitej polsko-litewskiej $w$ dobie rozbiorowej 1772-1815, red. M. Biskup, Warszawa-Toruń 1996, s. 61; V. Bu b e n, Rozdwojone wybory urzędników ziemskich na sejmiku elekcyjnym województwa nowogródzkiego 5 lutego 1777 roku, „Zeszyty Naukowe Uniwersytetu Jagiellońskiego. Prace Historyczne" 2006, z. 133, s. 56.

${ }^{7}$ W. Filipczak, Życie sejmikowe prowincji wielkopolskiej w latach 1780-1786, Łódź 2012, s. 609-610.

${ }^{8}$ H. W is ner, Rzeczpospolita Wazów, cz. 3 (Sławne Państwo Wielkie Księstwo Litewskie), Warszawa 2008, s. 124.

${ }^{9}$ Vol. leg., t. VII, s. 31 (ustawa: Rozdzielenie Trybunałów Koronnych); A. Lityńs ki, Sejmiki ziemskie 1764-1793. Dzieje reformy, Katowice 1988, s. 58.

10 Vol. leg., t. VII, s. 170 (ustawa: Sejmiki elekcyjne, deputackie i ziemskie); A. Lityński, op. cit., s. 60.
} 
kandydatów na sejmiku gospodarskim, który miał się zbierać dzień po zakończeniu obrad deputackich ${ }^{11}$. Kolejną ważną zmiana było ustalenie stałego terminu sejmików elekcyjnych na Litwie na dzień po lutowych („gromnicznych”) obradach gospodarskich. W tej sytuacji do ich zebrania nie był potrzebny uniwersał ${ }^{12}$.

Ustawa Porzadek sejmikowania z 1768 r. potwierdzała, że w Koronie, inaczej niż w Wielkim Księstwie, sejmiki elekcyjne maja wybierać czterech kandydatów na urzędy. Ustalono też, że uniwersał zwołujący zgromadzenie powinien być wydany najpóźniej sześć tygodni po śmierci urzędnika sądowego, a jego oblata miała nastąpić przynajmniej dwa tygodnie przed data sejmiku ${ }^{13}$. Uchwalona w 1775 r. ustawa Starostwa i królewszczyzny rozszerzała na urząd starosty grodowego zasadę elekcyjności, a wybór czterech kandydatów miał się odbywać na wzór elekcji sędziów i podkomorzych ${ }^{14}$. Sformułowanie konstytucji już wkrótce wzbudziło wątpliwości, jakie reguły mają obowiązywać na Litwie, gdzie od 1764 r. nie wybierano czterech kandydatów. Ostatecznie w Wielkim Księstwie sejmiki wyłaniające starostów dokonywały definitywnego wyboru, tak jak w przypadku innych urzędów ${ }^{15}$. Inna rzecz, że czasami pomijano sejmik elekcyjny, gdy urząd starosty był przekazywany w drodze cesji (ograniczone możliwości wyrażania zgody na cesje dawała monarsze ustawa $z 1778 \mathrm{r} .^{16}$ ).

Województwo sandomierskie zaliczane było do tzw. górnych, odgrywających szczególnie istotna rolę w izbie poselskiej. Słynęło też $z$ silnych tradycji średnioszlacheckich. Wojciech Kriegseisen

11 Vol. leg., t. VII, s. 31 (ustawa Rozdzielenie Trybunałów Koronnych); J. Michalski, Reforma sadownictwa na sejmie konwokacyjnym 1764 roku, [w:] Między wielka polityka a szlacheckim partykularzem. Studia z dziejów nowożytnej Polski i Europy ku czci Profesora Jacka Staszewskiego, Torun 1993, s. 310.

${ }^{12}$ Vol. leg., t. VII, s. 89 (ustawa: Sady ziemskie); A.B. Zakrzewski, Sejmik trocki..., s. 165.

13 Vol. leg., t. VII, s. 293 (ustawa: Porzadek sejmikowania); A. Lityński, Sejmiki województwa płockiego przed i w czasie Sejmu Czteroletniego. $Z$ badań nad organizacja i funkcjonowaniem, [w:] W dwusetna rocznice wolnego Sejmu. Ludzie - państwo - prawo czasów Sejmu Czteroletniego, red. A. Lityński, Katowice 1988 , s. 80.

${ }^{14}$ Vol. leg., t. VIII, wyd. J. Ohryzko, Petersburg 1860, s. 93 (ustawa: Starostwa i królewszczyzny); W. Fili pczak, op. cit., s. 609-610.

15 Szerzej na ten temat piszę w artykule: Elekcje ziemskich urzędników sadowych w czasach Rady Nieustajacej [w druku].

${ }^{16}$ Vol. leg., t. VIII, s. 580 (ustawa: Konsesnsa); W. Filipczak, Sejm 1778 roku, Warszawa 2000, s. 294-295. 
powołuje się na opinię tzw. Anonima Otwinowskiego, według którego sejmik sandomierski cieszył się największym uznaniem w Koronie, wyprzedzając nawet, znajdujące się wyżej w formalnej hierarchii, zgromadzenia województwa krakowskiego w Proszowicach i sejmiki wielkopolskie w Środzie ${ }^{17}$.

W czasach staropolskich województwo sandomierskie dzieliło się na siedem powiatów: sandomierski, wiślicki, pilzneński, radomski, opoczyński, chęciński (trzy ostatnie były określane jako ziemia radomska) i stężycki (występujący w źródłach jako ziemia stężycka) ${ }^{18}$. W wyniku pierwszego rozbioru Austria zajęła w całości powiat pilzneński i częściowo (obszary na południe od Wisły) sandomier$\mathrm{ski}^{19}$. W interesującym mnie okresie w województwie funkcjonowały trzy sady ziemskie: w Sandomierzu, Radomiu (utworzony na podstawie ustawy sejmu konwokacyjnego z 1764 r. dla powiatów radomskiego, opoczyńskiego i chęcińskiego ${ }^{20}$ ) oraz w Stężycy (dla „ziemi” stężyckiej - powołany w 1563 r. - decyzję w tej sprawie potwierdzono na sejmie $z$ 1563/1564 r. $)^{21}$. Na terenie województwa

${ }^{17}$ W. Kriegs e is en, Sejmiki Rzeczypospolitej szlacheckiej $w$ XVII i XVIII wieku, Warszawa 1991, s. 27. Na temat postaw politycznych szlachty sandomierskiej w drugiej połowie XVII w. i pierwszych dekadach XVIII w. por. też: id e m, Samorzad szlachecki $w$ Małopolsce $w$ latach 1669-1717, Warszawa 1989; Z. Trawicka, Życie polityczne szlachty województwa sandomierskiego $w$ drugiej połowie XVII w., [w:] Między monarcha a demokracja. Studia z dziejów Polski XV-XVIII wieku, red. A. Sucheni-Grabowska, A. Żaryn, Warszawa 1994, s. 270-305; J. Pielas, Szlachta sandomierska wobec najważniejszych wydarzeń politycznych pierwszych lat panowania Augusta II (1696-1704), [w:] Rzeczpospolita w dobie wielkiej wojny północnej, red. J. Muszyńska, Kielce 2001, s. 127-148; M. Soka1ski, Między królewskim majestatem a szlachecka wolnościa. Postawy polityczne szlachty małopolskiej w czasach Michała Korybuta Wiśniowieckiego, Kraków 2002.

18 Województwo sandomierskie $w$ drugiej połowie XVI wieku, red. W. Pałucki, cz. 2, Warszawa 1993, s. 32, 45-49; Z. Trawicka, Sejmik województwa sandomierskiego 1572-1696, Kielce 1985, s. 7-8.

19 Urzędnicy województwa sandomierskiego XVI-XVIII wieku. Spisy, oprac. K. Chłapowski i A. Falniowska-Gradowska, red. A. Gąsiorowski, Kórnik 1993, s. 5.

${ }^{20}$ Vol. leg., t. VII, s. 36 (konstytucja: Ustawa ziemstwa radomskiego $w$ województwie sandomirskim). Według Urzędników województwa sandomierskiego... (s. 7) w 1764 r. wskrzeszono także ziemstwo pilzneńskie, którego roki odbyły się raz w styczniu 1766 r. Jednak cytowana konstytucja o tym nie wspomina. Por. Vol. leg., t. VII, s. 210-211 (konstytucja z 1766 r.: Ustawa o rokach ziemskich województwa sandomierskiego $w$ powiatach sandomirskim, wiślickim i pilznińskim).

${ }^{21}$ Vol. leg., t. II, wyd. J. Ohryzko, Petersburg 1859, s. 28 (w ustawie Sad grodzki stężycki przyjętej przez sejm z 1563/1564 wspomina się, że decyzja w tej sprawie zapadła już na sejmie 1562/1563, lecz pominięto ustawę w jego konstytucjach). Por. też Urzędnicy województwa sandomierskiego..., s. 7, 136. 
sandomierskiego istniało sześć starostw grodowych (dla powiatów wiślickiego i pilzneńskiego w Nowym Mieście Korczynie), ale był tylko jeden podkomorzy ${ }^{22}$. Organizacja sadownictwa po pierwszym rozbiorze w Sandomierskiem nie budziła zadowolenia szlachty. Na sejm z 1780 r. został przygotowany przez Sandomierzan projekt w tej sprawie. Dotyczył on: po pierwsze, przeniesienia sądów ziemskich powiatów sandomierskich $z$ Wiślicy do Staszowa; po drugie, ustalenia, że sądy ziemskie radomskie będą się zbierać w Radomiu, a nie w trzech stolicach powiatów, które podlegały pod ich jurysdyk$\mathrm{cje}^{23}$. Podobne postulaty (umieszczenia ziemstwa w innym miejscu - w Opatowie lub w Sandomierzu) były powtarzane w instrukcjach poselskich przed kolejnymi sejmami ${ }^{24}$.

Chciałbym krótko uzasadnić ramy chronologiczne artykułu. Od grudnia 1777 do lipca 1783 r. w Opatowie sejmiki elekcyjne zbierały się aż siedem razy. W grudniu 1781 r. w Radomiu wybierano kandydatów na urząd podsędka radomskiego ${ }^{25}$. Przyjęcie jako daty końcowej lipca 1783 r. ma jeszcze jedna przyczynę. Dokonana wówczas elekcja kandydatów na podkomorzego sandomierskiego ${ }^{26}$ przekreślała istniejące wcześniej plany reformy tego urzędu. Sprawa miała wyraźny podtekst polityczny, o czym świadczą zarówno powody, dla których projekt w tej sprawie się pojawił, jak i przyczyny rezygnacji $z$ jego forsowania. W 1783 r. odbyły się także trzy sejmiki elekcyjne w Stężycy, jednak szczupłość dostępnych źródeł (nie jest znana żadna $z$ jego uchwał) nie pozwala na ich przed-

${ }^{22}$ Ibidem, s. 8.

${ }^{23}$ Przeniesienie sąów ziemskich powiatów sandomierskich z Wiślicy do Staszowa... (drukowany projekt konstytucji), Archiwum Główne Akt Dawnych w Warszawie [dalej: AGAD], Zbiór Popielów, sygn. [dalej: ZP] 110, k. 73; Dyaryusz Seymu wolnego ordynaryinego warszawskiego... 1780..., wyd. S. Badeni, Warszawa [1780], s. 351. Postulat, by sądy ziemskie radomskie obradowały tylko w Radomiu ( $z$ pozostawieniem możliwości składania relacji pozwów także w pozostałych grodach), pojawił się już w zaleceniach dla posłów na sejm w 1778 r.: Instrukcja poselska sejmiku w Opatowie z 17 VIII 1778, Biblioteka PAU i PAN w Krakowie, rkps [dalej: BPAU] 8341, s. 975-976.

${ }^{24} \mathrm{~W}$ instrukcji poselskiej sejmiku w Opatowie z 19 VIII 1782 r. postulowano przeniesienie sądów ziemskich powiatów sandomierskich w Wiślicy do Opatowa (BPAU 8341, s. 1082-1083). Z kolei w instrukcji sejmiku opatowskiego z 16 VIII 1784 r. proponowano przeprowadzkę ziemstwa $z$ Wiślicy do Sandomierza (AGAD, ZP 130, s. 143). Do Wiślicy przeniosła ziemstwo ustawa z 1766 r. (Vol. leg., t. VII, s. 210-211).

${ }^{25}$ Laudum sejmiku w Radomiu z 17 XII 1781, AGAD, tzw. Metryka Litewska, dział IX, sygn. [dalej: ML IX] 93, s. 28-31.

${ }^{26}$ Laudum sejmiku w Opatowie $z 16$ VII 1783, BPAU 8341, s. 1101-1112. 
stawienie $^{27}$. Pominięcie sejmików elekcyjnych z lat 1775-1776 wynika ze zmiany sytuacji politycznej po obradach skonfederowanego sejmu pod laska Andrzeja Mokronowskiego (i Andrzeja Ogińskiego) ${ }^{28}$. W interesujacym mnie okresie pierwszy sejmik elekcyjny, majacy za zadanie wybór kandydatów na podsędka i pisarza ziemskiego sandomierskich (wakujacych od dłuższego czasu), został zwołany przez wojewodę sandomierskiego Macieja Sołtyka (zarazem lidera miejscowych regalistów ${ }^{29}$ ) uniwersałem wydanym 17 listopada 1777 r. w Kurozwękach. Jak wynika $z$ laudum, został on oblatowany w księgach grodzkich sandomierskich i nowomiejskich ${ }^{30}$ (nowokorczyńskich) - dla powiatu wiślickiego. Niestety nie jest możliwa weryfikacja tej informacji, gdyż księgi sądowe $z$ tego obszaru się nie zachowały. Obrady w Opatowie, zagajone 4 grudnia 1777 r. przez M. Sołtyka, zostały określone jako sejmik „województwa sandomierskiego powiatów sandomierskich"31 - przez co należy rozumieć powiaty: sandomierski i wiślicki. Na marszałka koła rycerskiego wybrano stolnika sandomierskiego Leona Kochanowskiego, któremu do pomocy wyłoniono dwóch asesorów (miecznik pilzneński Jacek Dębicki i skarbnik chęciński Onufry Gosławski) ${ }^{32}$, co sugeruje, że swego przedstawiciela w tym gronie nie miał już powiat pilzneński, który odpadł po pierwszym rozbiorze. W pierwszej kolejności dokonano elekcji kandydatów na urząd podsędka. Zostali nimi: cześnik pilzneński i wicestarosta nowokorczyński (nowomiejski) Wawrzyniec Ankwicz (brat cioteczny marszałka L. Kochanowskiego ${ }^{33}$ ), łowczy wiślicki Michał Siemieński, wojski wiślicki Mikołaj

${ }^{27} \mathrm{~W} 1783$ r. stężyckie sądowe urzędy ziemskie otrzymali: Wojciech Żebrowski - sęstwo. Józef Pniewski - podsędkostwo, zaś Ignacy Rudnicki pisarstwo ziemskie (Urzędnicy województwa sandomierskiego..., s. 138, 140, 142).

${ }^{28} \mathrm{~J}$. M ich als ki, Sejm w czasach panowania Stanisława Augusta, [w:] Historia sejmu polskiego, red. J. Michalski, Warszawa 1984, s. 374-377; W. Stanek, Konfederacja sejmowa z 1776 roku - narzędzie dworskiego zamachu stanu, „Acta Universitatis Nicolai Copernici", Historia 28, 1993, s. 133-147.

${ }^{29}$ J. Michalski, Sejmiki poselskie 1788 r., cz. 2, „Przegląd Historyczny” 1960, t. LI, z. 2, s. 346; R. Cywiński, Sołtyk Maciej, [w:] Polski słownik biograficzny [dalej: PSB], t. XL, Warszawa-Kraków 2001, s. 411-412; W. Filipczak, Sejm 1778 roku..., s. 78; A. Danilczyk, W kręu afery Dogrumowej. Sejm 1786 roku, Warszawa 2010, s. 90-91.

${ }^{30}$ Laudum sejmiku w Opatowie z 4 XII 1777, BPAU 8341, s. 929.

${ }^{31}$ Ibidem, s. 930.

${ }^{32}$ Ibidem, s. 930, 936.

${ }^{33}$ "Ksiega domowa” Leona i Hieronima Kochanowskich 1763-1855, „Przegląd Historyczny" 1916, t. XX, z. 1, 195. 
Lipowski i starościc Adam Parys. W gronie czterech kandydatów do pisarstwa ziemskiego znaleźli się wojski sandomierski Wacław Tymiński, miecznik sandomierski Marcin Bystrzonowski, miecznik wiślicki i pisarz grodzki nowomiejski Adam Jan Kanty Borkowski oraz skarbnik sandomierski Antoni Michałowski ${ }^{34}$. Nie wszyscy jednak elekci zostali przez sejmik potraktowani w podobny sposób. W uchwale względom królewskim polecono szczególnie W. Ankwicza do urzędu podsędka, a A.J.K. Borkowskiego do pisarstwa ziemskiego $^{35}$. W czasie obrad szlachta sandomierska zajęła się jeszcze jednym zagadnieniem. Uznano, że Maksymilian Zborowski - „przeszły”, jak pisano, sędzia ziemski sandomierski „odpadł” od województwa sandomierskiego pod panowanie cesarskie. Powołano się na fakt, że sprawuje w Galicji obowiązki sędziowskie jako podsędek w sądach ziemskich pilzneńskich ${ }^{36}$ (ustanowionych przez władze austriackie). Uczestnicy sejmiku przypomnieli dawny wymóg posiadania przez sędziego ziemskiego posesji w województwie i wskazali na zapis Porzadku sejmikowania z 1768 r. dotyczacy dziedzicznej posesji potrzebnej do osiagnnięcia urzędów ziemskich ${ }^{37}$. Stwierdzono, że skoro majątki M. Zborowskiego znalazły się pod obcym panowaniem, a on przyjął obowiązki sędziowskie pod rządami cesarskimi, to w konsekwencji zrzekł się urzędu, który sprawował w Polsce. $\mathrm{W}$ tej sytuacji uznano sęstwo sandomierskie za wakujacce. Zobowiazano wojewodę M. Sołtyka, aby na podstawie uchwały sejmikowej niezwłocznie wydał uniwersał w celu wyboru kandydatów na urząd sędziego ziemskiego ${ }^{38}$. Zalecani przez sejmik kandydaci W. Ankwicz i A.J.K. Borkowski uzyskali królewskie nominacje ${ }^{39}$.

Wojewoda sandomierski wydał uniwersał na sejmik elekcyjny 22 grudnia 1777 r. (został oblatowany w księgach grodzkich sandomierskich i nowokorczyńskich). Powołał się w nim na wspomniane

${ }^{34}$ Laudum sejmiku w Opatowie z 4 XII 1777, BPAU 8341, s. 930-931. W wydawnictwie Urzędnicy województwa sandomierskiego..., s. 100, 109, błędnie podano, że elekcja kandydatów odbyła się 2 XII 1777 r. Jako na źródło informacji powołano się na Kronikę domowa, choć jest w niej napisane, że L. Kochanowski 2 grudnia wyjechał na sejmik, który „przypadał” 4 grudnia („Kronika domowa”..., s. 195).

${ }^{35}$ Laudum sejmiku w Opatowie z 4 XII 1777, BPAU 8341, s. 931-932.

${ }^{36}$ Ibidem, s. 933.

37 Por. Vol. leg., t. VII, s. 293 (konstytucja: Porzadek sejmikowania). W ustawie mowa jest, że bierne prawo wyborcze na sejmikach maja tylko posesjonaci w danym województwie. Por. też A. Lityń s ki, Sejmiki ziemskie 1764-1793..., s. 116.

${ }^{38}$ Laudum sejmiku w Opatowie z 4 XII 1777, BPAU 8341, s. 933-935.

${ }^{39}$ Urzędnicy województwa sandomierskiego..., s. 100, 108-109. 
laudum sejmikowe z 4 grudnia. Termin wyboru kandydatów na sędziego M. Sołtyk ustalił na 12 stycznia $1778 \mathrm{r}^{40} \mathrm{~W}$ tym dniu obrady w Opatowie zostały zagajone przez kasztelana zawichojskiego Ksawerego Kochanowskiego. Obradom marszałkował choraży i wicestarosta sandomierski Michał Leszczyński, któremu „przydano" do pomocy dwóch asesorów. Zostali nimi stolnik L. Kochanowski (marszałek poprzedniego sejmiku) i cześnik wiślicki Franciszek Rupniewski ${ }^{41}$. Zgodnie $z$ uniwersałem wojewody szlachta „powiatów sandomierskich” wybrała czterech kandydatów na urząd sędziego ziemskiego. Na pierwszym miejscu wymieniony został nowy podsędek W. Ankwicz, za którym zaniesiono „najszczególniejsze” prośby do tronu. Pozostałych kandydatów wyłoniono, gdyż (jak pisano w laudum) wymagało tego prawo. Byli nimi: stolnik wiślicki Stefan Gołuchowski, wojski sandomierski Wacław Tymiński i wojski wiślicki Mikołaj Lipowski ${ }^{42}$. W dalszej części uchwały zajęto się sprawami, które zwykle stanowiły przedmiot obrad gospodarskich. Określono procedury postępowania, z zapieczętowanymi przez marszałka poprzedniego sejmiku (L. Kochanowskiego) aktami ziemskimi w Wiślicy. Zalecano także, by sprawy obywateli sandomierskich, które w wyniku długotrwałych wakansów sądzone były w sadzie ziemskim radomskim, zostały odesłane do ziemstwa sandomierskiego ${ }^{43}$.

Należy podkreślić, że decyzje sejmików opatowskich z grudnia 1777 i stycznia 1778 r. były problematyczne $z$ prawnego punktu widzenia. Ustawodawstwo nie przewidywało innego trybu pojawiania się wakansów niż śmierć, rezygnacja lub awans posiadacza królewskiej nominacji. Leon Kochanowski pisał, że w dniu styczniowych obrad otrzymał wiadomość z Warszawy, „iż tamże wzrastały przeciwności przeciwko sejmikowi temuż". Chciano „illegalizować” zgromadzenie, ponieważ M. Zborowski nie uczynił rezygnacji

${ }^{40}$ Laudum sejmiku w Opatowie z 12 I 1778, Biblioteka Jagiellońska w Krakowie, rkps [dalej: BJ] 7600, k. 39 (także: BPAU 8341, s. 937-938). Leon Kochanowski nieściśle podał, że sejmik odbył się 13 I 1778 r. („Kronika domowa”..., s. 195). Za Kronika domowa datę 13 stycznia podano w: Urzędnicy województwa sandomierskiego..., s. 114.

${ }^{41}$ Laudum sejmiku w Opatowie z 12 I 1778, BJ 7600, s. 39-39v (także: BPAU 8341, s. 938-939).

${ }^{42}$ Laudum sejmiku w Opatowie z 12 I 1778, BJ 7600, s. 39v (także: BPAU 8341, s. 939-941).

${ }^{43}$ Laudum sejmiku w Opatowie z 12 I 1778, BJ 7600, s. 39v-40 (także: BPAU 8341, s. 941-944). 
$z$ sęstwa ${ }^{44}$. Do stolicy udali się (w styczniu) stolnik sandomierski L. Kochanowski, a wkrótce po nim podsędek W. Ankwicz (faworyzowany przez sejmik kandydat do wakansu), którzy przywiózł listy wojewody M. Sołtyka do kanclerza koronnego Andrzeja Młodziejowskiego i sekretarza wielkiego koronnego Jacka Ogrodzkiego ${ }^{45}$. Z Ksiegi domowej L. Kochanowskiego wynika, że 18 stycznia wyjechał on do Warszawy, gdzie uzyskał audiencję u króla. W jej trakcie stolnik sandomierski miał przez przeszło dwie godziny przekonywać monarchę o „złośliwych” intrygach strony przeciwnej. Jednocześnie sugerował, by dotychczasowy sędzia (w zamian za rezygnację) otrzymał Order Św. Stanisława ${ }^{46}$. Krażyły bowiem wieści, że M. Zborowski zdołał uzyskać protekcję kanclerza koronnego Andrzeja Młodziejowskiego i posła austriackiego Karla Reviczkiego, który miał traktować sprawę jako naruszenie traktatu polsko-austriackiego ${ }^{47}$. W gazetce pisanej przytaczano argument, że sędzia ziemski sandomierski nie wypełniał swoich obowiązków ze względu na funkcję pełnioną w Trybunale Lwowskim. Wskazywano również, że jeszcze nie minęło sześć lat przewidziane w traktacie (a właściwie w dołączonym do niego Akcie osobnym), w ciagu których należało podjąć decyzję dotyczaca zachowania obywatelstwa w Polsce lub przeniesienia się do Galicji ${ }^{48}$. Rzeczywiście K. Reviczky podał do Rady Nieustającej note w sprawie M. Zborowskiego ${ }^{49}$. Dwuznaczna była rola Młodziejowskiego, co znajduje potwierdzenie w korespondencji. Jacek Ogrodzki (szef Gabinetu Stanisława Augusta ${ }^{50}$ ) pisał, że kanclerz niepotrzebnie podniósł zastrzeżenia przed odjazdem króla z Warszawy. Szef Gabinetu sugerował, że działania pieczętarza w tej sprawie mógł inspirować jeden $z$ przywódców opozycji magnackiej (a zarazem starosta wiślicki) Stanisław Lubomirski, marszałek wielki koronny ${ }^{51}$.

44 „Kronika domowa”..., s. 195.

45 Jacek Ogrodzki do króla z 23 I 1778, Biblioteka Czartoryskich w Krakowie, rkps [dalej: $\mathrm{BCz}$ ] 799, s. 1395.

46 "Kronika domowa”..., s. 195.

${ }^{47}$ Wiadomość z Warszawy z 9 II 1778, BPAU 993, s. 122-123; A. Młodziejowski do króla z 14 I 1778, BCz 799, s. 1391; „Kronika domowa”..., s. 195.

48 Wiadomość z Warszawy z 5 II 1778, BJ 6799, k. 10. Por. VL, t. VIII, wyd. J. Ohryzko, Petersburg 1860, s. 39-40 (Akt osobny do traktatu między Rzeczapospolita a Marią Teresa).

49 A. Młodziejowski do króla z 14 I 1778, BCz 799, s. 1391.

50 M. Rymszyna, Gabinet Stanisława Augusta, Warszawa 1962, s. 70-71; J. Michalski, Ogrodzki Jacek, [w:] PSB, t. XXIII, Wrocław 1978, s. 649-650.

${ }^{51}$ Jacek Ogrodzki do króla z 23 I 1778, BCz 799, s. 1395. Na temat roli politycznej S. Lubomirskiego por. E. Rostworowski, Ostatni król Rzeczypospolitej. 
Z listu A. Młodziejowskiego do wojewody M. Sołtyka wiadomo, że M. Zborowski w początkach stycznia złożył rezygnację $z$ urzędu. Kanclerz jednak miał watpliwości, czy została ona napisana w sposób prawidłowy i twierdził, że mogła dostarczyć posłowi cesarskiemu argumentów w sprawie naruszenia artykułów odrębnych traktatu cesyjnego z Austrią. Prosił więc o skłonienie M. Zborowskiego do podpisania nowej rezygnacji ${ }^{52}$.

Ostatecznie W. Ankwicz awansował $z$ podsędkostwa na urząd sędziego ziemskiego sandomierskiego (przywilej nosił datę 7 marca 1778 r. $)^{53}$. Maciej Sołtyk wydał więc 13 marca 1778 r. uniwersal zwołujacy na 30 marca sejmik elekcyjny do Opatowa (został oblatowany $\mathrm{w}$ grodach sandomierskim i nowokorczyńskim) ${ }^{54}$. W tym dniu wojewoda sandomierski w Opatowie zagaił obrady, w czasie których na marszałka koła rycerskiego został wybrany kasztelanic połaniecki Józef Niemirycz, chorąży kawalerii narodowej. Jego pomocnikami zostali, jako asesorowie, generał adiutant Andrzej Borzykowski i podstolic sandomierski Filip Mikułowski. Na kandydatów do podsędkostwa wybrano jednogłośnie: cześnika stężyckiego Józefa Brzeskiego, skarbnika sandomierskiego Antoniego Mikułowskiego, skarbnika pilzneńskiego Eliasza Reklewskiego i starościca lelowskiego Antoniego Marchockiego. I tym razem nie wszyscy pretendenci zostali potraktowani jednakowo, gdyż szczególne poparcie zgromadzenia uzyskał cześnik J. Brzeski ${ }^{55}$. On też ostatecznie uzyskał królewską nominację (z 11 kwietnia 1778 r.) na urząd podsędka sandomierskiego ${ }^{56}$.

Już wkrótce M. Sołtyk musiał ponownie zwoływać szlachtę powiatów sandomierskich na sejmik elekcyjny. Spowodował to zgon, niedawno mianowanego pisarzem ziemskim, A.J.K. Borkowskiego. Wojewoda sandomierski wydał 6 maja 1778 r. w Kurozwękach uniwersał zwołujący elekcję kandydatów (oblatowano go w księgach grodzkich sandomierskich i nowokorczyńskich) ${ }^{57}$. Obrady w Opatowie 21 maja zagaił M. Sołtyk, a na marszałka sejmiku wybra-

Geneza i upadek Konstytucji 3 Maja, Warszawa 1966, s. 88-94; J. Michalski, Lubomirski Stanisław, [w:] PSB, t. XVIII, Wrocław 1973, s. 54-55.

${ }^{52}$ A. Młodziejowski do M. Sołtyka z 8 III 1778, AGAD, Varia Oddziału I, sygn. 15, s. $1273-1274$.

${ }^{53}$ Urzędnicy województwa sandomierskiego..., s. 114.

${ }^{54}$ Laudum sejmiku w Opatowie z 30 III 1778, BPAU 8341, s. 945-946.

${ }^{55}$ Ibidem, s. 946-948.

${ }^{56}$ Urzędnicy województwa sandomierskiego..., s. 109.

${ }^{57}$ Laudum sejmiku w Opatowie z 21 V 1778, BPAU 8341, s. 949-950. 
no starostę nowokorczyńskiego Jana Michała z Nagłowic Reya. Tradycyjnie powołano dwóch asesorów, którymi zostali chorąży wiślicki Konstanty Bogoria Skotnicki i podstoli sandomierski Józef Siedlecki ${ }^{58}$, więc dość wysocy urzędnicy ziemscy. Na kandydatów do pisarstwa ziemskiego sandomierskiego wybrani byli: generał adiutant Ignacy Bukowski, komornicy graniczni sandomierscy Józef Bogoria Skotnicki i Kazimierz Boniecki oraz pisarz grodzki nowomiejski (nowokorczyński) Łukasz Mikułowski. W laudum znalazł się też zapis, że choć pretendenci sa godni urzędu, to szczególnie względom króla polecano, ostatniego $z$ podanych w uchwale kandydatów, Ł. Mikułowskiego ${ }^{59}$. Kanclerz A. Młodziejowski pisał, że miał on wsparcie nie tylko od „pierwszeństwa” (tzn. najwyższych urzędników województwa), lecz także od ogółu ziemian sandomierskich ${ }^{60}$. Łukasz Mikułowski już wkrótce uzyskał nominację na urząd pisarza ziemskiego (noszacą datę 3 czerwca 1778 r.) ${ }^{61}$.

Kolejny sejmik elekcyjny zebrał się po przeszło trzech latach. Jesienia 1781 r., po śmierci Antoniego Radońskiego (został wybrany kandydatem na urząd 23 października 1775 r. na sejmiku w Radomiu ${ }^{62}$ ), zawakował urząd podsędka radomskiego ${ }^{63}$. Jednym $z$ pretendentów do godności był podczaszy (i pisarz grodzki) opoczyński Marcin Libiszowski. W początkach listopada wpływowy w województwie sandomierskim podkanclerzy Jacek Małachowski napisał do Adama Cieciszowskiego (od 1780 r. szefa królewskiego Gabinetu ${ }^{64}$ ) list $z$ poparciem jego aspiracji ${ }^{65}$. Wskazywał $\mathrm{w}$ nim na dotychczasowe zasługi podczaszego dla województwa. Marcin Libiszowski uzyskał już dwa razy funkcję poselska, był także deputatem na Trybunał Koronny, a szlachta wybierała go na surogatora (który zastępował nieobecnych ziemskich urzędników sądowych) ${ }^{66}$. Podczaszy opoczyński podobno uzyskał obietnicę poparcia od lide-

${ }^{58}$ Ibidem, s. 950-951.

${ }^{59}$ Ibidem, s. 951-952.

${ }^{60}$ A. Młodziejowski do J.M. Reya z 22 V 1778, AGAD, Varia Oddziału I, sygn. 15, s. 1343.

${ }^{61}$ Urzędnicy województwa sandomierskiego..., s. 100.

${ }^{62}$ Laudum sejmiku w Radomiu z 23 X 1775, BCz 930, s. 347-349.

${ }^{63}$ Urzędnicy województwa sandomierskiego..., s. 76.

${ }^{64}$ M. Rymszyna, op. cit., s. 114-115.

65 J. Małachowski do A. Cieciszowskiego z 2 XI 1781, BCz 673, s. 61. Na temat roli J. Małachowskiego w życiu publicznym por. P. Ols zewski, Kanclerz Jacek Nałęcz Małachowski (1737-1821), Kielce 2013, s. 120-134.

${ }^{66} \mathrm{~J}$. Małachowski do A. Cieciszowskiego z 2 XI 1781, BCz 673, s. 61. 
ra sandomierskich regalistów M. Sołtyka. Na postawę tego ostatniego mogła wpłynać presja ze strony podkanclerzego koronnego. Po śmierci A. Radońskiego J. Małachowski zażądał od wojewody sandomierskiego przesłania mu uniwersału na sejmik elekcyjny. W liście do Michała Strasza, łowczego opoczyńskiego, M. Sołtyk zaprzeczał jednak twierdzeniu, że polecał M. Libiszowskiego Stanisławowi Augustowi ${ }^{67}$. Michał Strasz, ówczesny deputat sandomierski (wybrany 15 lipca 1781 r.) ${ }^{68}$, był kolejnym aspirantem do podsędkostwa radomskiego. Jego starania o urząd popierali, w liście do króla $z$ końca listopada, kierownicy obradującego od 1 września 1781 r. w Piotrkowie Trybunału Koronnego - marszałek Franciszek Ksawery Kęszycki, kasztelan gnieźnieński a zarazem czołowy wielkopolski regalista, oraz prezydent trybunalski ks. Sebastian Sierakowski ${ }^{69}$. Mimo początkowego oporu ze strony Małachowskich i M. Sołtyka, ze względu na wcześniejsze obietnice składane M. Libiszowskiemu, na dworze poparcie uzyskał M. Strasz. Miał on zreszta zasługi wobec wojewody sieradzkiego i starosty opoczyńskiego Mikołaja Małachowskiego ${ }^{70}$. Zabiegi łowczego opoczyńskiego wspierał także wpływowy stronnik dworu Jan Kicki, koniuszy koronny ${ }^{71}$. W tej sprawie pisali do niego ks. S. Sierakowski i F.K. Kęszycki, który wskazywał, że pominięcie deputata sandomierskiego podczas nadania urzędu może spowodować niezadowolenie innych sędziów trybunalskich ${ }^{72}$. W powyższej kwestii list skierowano również do biskupa płockiego Michała Poniatowskiego, jednego z przywódców stronnictwa regalistycznego w Koronie ${ }^{73}$.

${ }^{67}$ Ibidem, s. 61-62; M. Sołtyk do M. Strasza z 25 XI 1781, BCz 930, s. 343-344.

${ }^{68}$ Z. A nu sik, Strasz Michat, [w:] PSB, t. XLIV, Warszawa-Kraków 2006-2007, s. 210 .

${ }^{69}$ F.K. Kęszycki i S. Sierakowski do króla z 27 XI 1781, BCz 930, s. 169-170. Por. też W. Filipczak, Życie sejmikowe..., s. 72, 206-211.

${ }^{70}$ J. Zambrzycki do J. Kickiego z 28 XI 1781, BCz 932, s. 783-784.

${ }^{71}$ M. Strasz do J. Kickiego z 3 XII 1781, BCz 930, s. 729. Por. też W. Se rczyk, Kicki Jan, [w:] PSB, t. XII, Wrocław-Warszawa-Kraków 1966-1967, s. 388.

${ }^{72}$ F.K. Kęszycki do J. Kickiego z 28 XI 1781, BCz 924, s. 195-196; S. Sierakowski do J. Kickiego z 27 XI 1781, BCz 930, s. 165.

${ }^{73}$ F.K. Kęszycki do J. Kickiego z 28 XI 1781, BCz 924, s. 195. Na temat roli królewskiego brata w stronnictwie dworskim por. J. Michalski, Sejmiki poselskie..., cz. 1, „Przegląd Historyczny” 1960, t. LI, z. 1, s. 53; Z. Zi eliń s ka, Poniatowski Michał Jerzy, [w:] PSB, t. XXVII, Wrocław 1983, s. 457; W. Fili p czak, Sejmiki województwa płockiego 1780-1786, „Przegląd Nauk Historycznych” 2009, R. VIII, nr 2, s. 24-26, 40-41, 60; i d e m, Sejmikiziemi nurskiej 1780-1786, „Przegląd Nauk Historycznych" 2014, R. XIII, nr 1, s. 28; D. Rolnik, Sejmiki poselskie drugiej 
Uniwersałem z 15 listopada 1781 r. M. Sołtyk zwołał sejmik elekcyjny do Radomia na 17 grudnia tego roku. W liście do M. Strasza wojewoda sandomierski wczesny termin zgromadzenia tłumaczył chęcia utrzymania kadencji sądowej ${ }^{74}$. Obrady sejmiku „powiatów radomskich” zagaił kasztelan wiślicki Ksawery Kochanowski (więc senator z powiatów sandomierskich). Marszałkiem koła rycerskiego został choraży chęciński Andrzej Dobiecki. Do pomocy przydzielono mu trzech asesorów, po jednym $z$ każdego powiatu ( $z$ radomskiego - podstoli stężycki Józef Niemirycz, marszałek sejmiku z marca 1778 r.; z opoczyńskiego - wojski opoczyński Anastazy Radoński; $z$ chęcińskiego - stolnik łęczycki Rupert Dunin ${ }^{75}$, opozycyjny poseł łęczycki na pierwszy sejm rozbiorowy ${ }^{76}$ ). Na kandydatów do podsędkostwa radomskiego wybrano: łowczego opoczyńskiego M. Strasza, pisarza ziemskiego radomskiego A. Mikułowskiego; wojskiego większego i pisarza grodzkiego chęcińskiego Jana Kantego Karwosieckiego oraz starostę siemiechowskiego Ignacego Krasińskiego. Inaczej niż na sejmikach opatowskich żaden $z$ pretendentów nie został szczególnie wyróżniony ${ }^{77}$ (pomijając oczywiście kolejność ich umieszczenia w uchwale). $Z$ pretendowania do urzędu zrezygnował więc podczaszy M. Libiszowski, podobno ulegając perswazjom podkanclerzego J. Małachowskiego ${ }^{78}$. Pisarz ziemski A. Mikułowski w staraniach o awans szukał, już po sejmiku, protekcji marszałka wielkiego koronnego S. Lubomirskiego ${ }^{79}$. Podobno jednak Mikułowski doszedł do porozumienia ze Straszem, choć nie wiadomo, czego ta umowa dotyczyła ${ }^{80}$. Już dwa dni po sejmiku (19 grudnia 1781) nominację na urząd uzyskał dotychczasowy łowczy opoczyński ${ }^{81}$.

połowy panowania Stanisława Augusta. O czynnikach i motywacjach decydujacych o wyborze posłów sejmowych, [w:] Po unii-sejmiki szlacheckie..., s. 334-336.

${ }^{74}$ M. Sołtyk do M. Strasza z 25 XI 1781, BCz 930, s. 343-344.

${ }^{75}$ Laudum sejmiku w Radomiu z 17 XII 1781, AGAD, ML IX/93, s. 28-29.

${ }^{76}$ R. Ch oj e cki, Patriotyczna opozycja na sejmie 1773 r., „Przegląd Historyczny” 1972, R. LXXIX, s. 550; H. Żerek-Kleszcz, Posłowie łęczyccy 1764-1792 $i$ ich status majątkowy, „Acta Universitatis Lodziensis”, Folia historica 72, 2001, s. 142 .

${ }^{77}$ Laudum sejmiku w Radomiu z 17 XII 1781, AGAD, ML IX/93, s. 29-30.

78 J. Małachowski do [A. Cieciszowskiego?], bez daty, $\mathrm{BCz} 673$, s. 53. Marcin Libiszowski uzyskał obietnicę, że jego brat stryjeczny zostanie skarbnikiem opoczyńskim.

${ }^{79}$ S. Lubomirski do J. Małachowskiego, bez daty, $\mathrm{BCz} 673$, s. 55.

${ }^{80} \mathrm{~J}$. Małachowski do [A. Cieciszowskiego?], bez daty, $\mathrm{BCz} 673$, s. 53.

${ }^{81}$ Urzędnicy województwa sandomierskiego..., s. 76. 
Pod koniec 1781 r. zmarł sędzia ziemski sandomierski W. An$\mathrm{kwicz}^{82}$. Na obsadę tego urzędu próbował wpłynąć stolnik koronny Kajetan Olizar, który jako marszałek niesławnego Trybunału Koronnego w kadencji 1780/1781 czuł się uprawniony do zabiegania o wakanse dla deputatów pracujących pod jego dyrekcja ${ }^{83}$. Kajetan Olizar, jeden $z$ liderów wołyńskich regalistów, próbował umieścić na urzędzie sędziego sandomierskiego Józefa Chojnackiego, podsędka łuckiego (wcześniej sędziego grodzkiego nowokorczyńskiego). Stolnik koronny powoływał się w tej sprawie na inicjatywę obywateli sandomierskich. Ponieważ jednak ostrzegano go, że takie działania moga być źle przyjęte przez wojewodę M. Sołtyka, więc sugerował królowi, by w tej sprawie skorzystać z pośrednictwa koniuszego koronnego J. Kickiego. Kajetan Olizar informował również monarchę, że nie jest prawdą, iż o sęstwo sandomierskie zabiega deputat krakowski Karol Głębocki ${ }^{84}$.

Dnia 10 stycznia 1782 r. w Kurozwękach M. Sołtyk wydał uniwersał zwołujaccy sejmik elekcyjny, który oblatowano dwa dni później $\mathrm{w}$ grodach sandomierskim i nowokorczyńskim ${ }^{85}$. Wojewoda sandomierski zagaił 28 stycznia 1782 r. obrady w Opatowie. $\mathrm{Na}$ marszałka koła rycerskiego został wybrany wojski większy sandomierski Marcin Bystrzonowski. Do pomocy dodano mu dwóch asesorów (podwojewodziego sandomierskiego Andrzeja Borzykowskiego i pisarza grodzkiego sandomierskiego Antoniego Ławskiego) ${ }^{86}$. Grono czterech kandydatów do sęstwa ziemskiego tworzyli: podczaszy wiślicki Franciszek Rupniewski, cześnik sandomierski Antoni Jagniątkowski, sędzia grodzki sandomierski Stanisław Młodecki i starosta makowski (?) Franciszek Krokowski. Szczególnie rekomendowanym przez sejmik kandydatem był podczaszy F. Rupniewski ${ }^{87}$. Otrzymał on nominację na urząd sędziego ziemskiego w ostatnim dniu stycznia ${ }^{88}$.

${ }^{82}$ Ibidem, s. 114.

${ }^{83}$ W. Szczygielski, Olizar Franciszek Kajetan, [w:] PSB, t. XXIII, Wrocław 1978, s. 813; W. Fili pczak, Życie sejmikowe..., s. 54-55.

${ }^{84} \mathrm{~K}$. Olizar do króla $z$ grudnia $1781, \mathrm{BCz} 681$, s. 481.

${ }^{85}$ Laudum sejmiku w Opatowie z 28 I 1782, AGAD, ML IX/93, s. 32-33 (także: BPAU 8341, s. 1049-1051 - laudum jest datowane na 20 I 1782).

${ }^{86}$ Laudum sejmiku w Opatowie z 28 I 1782, AGAD, ML IX/93, s. 33-34 (także: BPAU 8341, s. 1051-1053).

${ }^{87}$ Laudum sejmiku w Opatowie z 28 I 1782, AGAD, ML IX/93, s. 34 (także: BPAU 8341, s. 105-1055).

${ }^{88}$ Urzędnicy województwa sandomierskiego..., s. 114. 
W 1782 r. zawakowało pióro ziemskie sandomierskie po śmierci Ł. Mikułowskiego. Niestety uchwała sejmiku elekcyjnego nie jest znana. Wiadomo jednak, że o urząd zabiegał podstarości nowokorczyński Karol Głębocki (w kadencji 1780-1781 deputat krakowski, poseł na sejm z 1782 r. i na Sejm Wielki), który prosił Stanisława Augusta, by zalecił M. Sołtykowi starania majace na celu umieszczenie go w gronie kandydatów ${ }^{89}$. W czerwcu 1782 r. podkomorzy krakowski Michał Walewski zabiegał o pióro ziemskie dla pisarza grodzkiego nowokorczyńskiego (nowomiejskiego) Jana Weryhy Darowskiego ${ }^{90}$, 15 lipca 1780 r. wybranego w Opatowie na deputata trybunalskiego $z$ województwa sandomierskiego ${ }^{91}$. W liście $z 22$ sierpnia 1782, trzy dni po sejmiku przedsejmowym, kasztelan sandomierski Adam Łącki rekomendował do urzędu pisarza ziemskiego skarbnika i sędziego grodzkiego sandomierskiego S. Młodeckiego, który był jednym z czwórki wybranych na sejmiku kandydatów ${ }^{92}$. Jemu też niemal miesiąc później (19 września 1782) przypadła nominacja na urząd ${ }^{93}$.

Jeszcze zanim odbył się sejmik pisarski, zawakowało podkomorstwo sandomierskie po śmierci Antoniego Potkańskiego ${ }^{94}$, co rzecz jasna spowodowało zabiegi o wakans. W lutym i w czerwcu $1782 \mathrm{r}$. prymas Antoni Ostrowski pisał do króla listy z prośbą o urząd dla chorażego chęcińskiego Andrzeja Dobieckiego ${ }^{95}$. W lutym 1782 r. aspiracje do podkomorstwa zgłaszał także E. Prażmowski, który za najpoważniejszego konkurenta uważał stolnika sandomierskiego Leona Kochanowskiego. Inny potencjalny konkurent, choraży sandomierski Michał Leszczyński miał, jego zdaniem, nie aspirować do wakansu, gdyż jego objęcie wymagałoby rezygnacji z podstarostwa grodzkiego ${ }^{96}$.

${ }^{89}$ K. Głębocki do króla, bez daty, BCz 663, s. 103; E. Ro s tw o r ow s ki, Głębocki Karol, [w:] PSB, t. VIII, Wrocław 1959, s. 110; W. Szczygie1ski, Referendum trzeciomajowe. Sejmiki lutowe 1792 roku, Łódź 1994, s. 175-179.

${ }^{90}$ M. Walewski do A. Cieciszowskiego z 23 VI 1782, BCz 694, s. 51. W 1780 r., kiedy M. Walewski z polecenia króla skutecznie starał się ułatwić K. Olizarowi droge do laski trybunalskiej, deputat sandomierski J. Darowski pomagał mu w tym zadaniu, por. M. Kobierecki, Walewscy herbu Kolumna $w$ XVII-XVIII wieku. Genealogia. Majętności. Działalność publiczna, Łódź 2008, s. 189.

${ }^{91}$ Laudum sejmiku w Opatowie $z 15$ VII 1780, BPAU 8341, s. 1000.

92 A. Łącki do króla z 22 VIII 1782, BCz 671, s. 71.

${ }^{93}$ Urzędnicy województwa sandomierskiego..., s. 101.

${ }^{94}$ W. Sz czy gi i ls ki, Potkański Antoni, [w:] PSB, t. XXVII, Wrocław 1983, s. 721.

95 A. Ostrowski do króla z 19 II 1782 i A. Ostrowski do króla z 8 VI 1782, $\mathrm{BCz}$ 678, s. 659-660, 673.

${ }^{96}$ E. Prażmowski do NN $z$ przełomu lutego/marca 1782 (na liście jest data 29 lutego!), $\mathrm{BCz} 683$, s. 547. 
Ze zwołaniem sejmiku jednak zwlekano. Było to zwiąane $z$ zaakceptowanym przez króla projektem podziału podkomorstwa sandomierskiego. Miejscowy wojewoda Maciej Sołtyk nie wydawał uniwersału przed sejmem, który miał się zebrać na jesieni tego roku. Chodziło o realizację projektu stworzenia w Sandomierskiem trzech podkomorstw, co oczywiście wymagało przyjęcia przez parlament odpowiedniej ustawy ${ }^{97}$. Stanisław August zalecał, by propozycja znalazła się w instrukcji poselskiej, jednak z zastrzeżeniem, że wszystkie elekcje podkomorskie miały się odbywać w Opatowie $^{98}$. Odpowiedni punkt znalazł się w zaleceniach uchwalonych na sejmiku z 19-20 sierpnia 1782 r. dla reprezentantów województwa sandomierskiego ${ }^{99}$. O planach tych, uzgadnianych wcześniej $z$ M. Sołtykiem, w końcu czerwca monarcha poinformował arcybiskupa A. Ostrowskiego, zaznaczając, że jednym z podkomorzych miał zostać A. Dobiecki ${ }^{100}$.

Brak uniwersału zwołującego sejmik elekcyjny spowodował jednak pogłoski, że A. Dobiecki będzie chciał przeprowadzić elekcję kandydatów w terminie obrad gospodarskich (na podstawie ustawy z 1764 r.), dzień po zgromadzeniu deputackim ${ }^{101}$ (16 lipca 1782). Wojewoda M. Sołtyk uspokajał monarchę, że wbrew początkowym wiadomościom przekazanym sekretarzowi Stanisławowi Badeniemu, chorąży chęciński nie miał takich zamiarów, a obecni na sejmiku urzędnicy zgodzili się czekać na „tryplikowanie” podkomorstw ${ }^{102}$.

W listopadzie 1782 r. (po zakończeniu sejmu) okazało się, że sprawa jest nieaktualna. Stanisław August polecił M. Sołtykowi zwołać sejmik w Opatowie dopiero na 28 kwietnia 1783 r., więc przeszło rok po pojawieniu się wakansu ${ }^{103}$. Monarcha w korespondencji zalecał popieranie na sejmiku A. Dobieckiego. Za pośrednictwem kasztelanowej krakowskiej Zofii Lubomirskiej król starał

${ }^{97}$ W. Filipczak, Życie sejmikowe..., s. 617-618.

${ }^{98}$ Król do M. Sołtyka z 29 V 1782, BJ 7597, k. 27 (minuta listu: BCz 688, s. $127-128)$.

${ }^{99}$ Instrukcja poselska sejmiku w Opatowie $z$ 19-20 VIII 1782, BPAU 8341, s. 1083-1084; W. Filipczak, Życie sejmikowe..., s. 617-618.

${ }^{100}$ Król do A. Ostrowskiego z 26 (?) VI 1782, BCz 678, s. 677.

${ }^{101}$ Król do M. Sołtyka z 18 VII 1782, BJ 7597, k. 31 (minuta listu: BCz 688, s. 141).

${ }^{102}$ M. Sołtyk do króla z 18 VII 1782, BCz 688, s. 135-136.

${ }^{103}$ Król do M. Sołtyka z 16 XI 1782, BCz 688, s. 165; W. Filipczak, Życie sejmikowe..., s. 618. 
się skłonić do rezygnacji z zabiegów o urząd starostę siemiechowskiego I. Krasińskiego ${ }^{104}$. O wsparcie dla chorążego chęcińskiego Stanisław August zwracał się w lutym 1783 do J. Małachowskiego $^{105}$. Podkanclerzy koronny nie odmówił pomocy, ale wyrażał niezadowolenie, że o stanowisku monarchy dowiedział się tak późno. Stwierdził, że gdyby otrzymał informację w tej sprawie dwa miesiące wcześniej, nie złożyłby obietnic w odpowiedzi na prośby stolnika L. Kochanowskiego i sędziego ziemskiego radomskiego Karola Wąsowicza $^{106}$. Innym aspirantem do podkomorstwa był chorąży wiślicki Konstanty Skotnicki (w 1782 r. poseł sandomierski ${ }^{107}$ ), który jednak pod wpływem monarchy wycofał się $z$ rywalizacji jeszcze przed sejmikiem $^{108}$. Maciej Sołtyk w liście do Stanisława Augusta z 16 lipca 1783 r., napisanym dzień po sejmiku deputackim w Opatowie, wyrażał przekonanie, że wybór kandydatów do podkomorstwa dokona się jednogłośnie, a jednym $z$ nich będzie A. Dobiecki. Podkreślał lojalna postawę stolnika L. Kochanowskiego, jego rodziny oraz I. Krasińskiego, a także nieobecność sędziego K. Wąsowicza ${ }^{109}$.

Maciej Sołtyk zwołał elekcję kandydatów do podkomorstwa uniwersałem z 25 marca 1783 r. wydanym w Kurozwękach, który został (jak czytamy w laudum) wniesiony „do grodów wszystkich województwa"110. W sejmiku, który zebrał się w Opatowie 16 lipca 1783 r., oprócz wojewody sandomierskiego (zagaił on obrady) uczestniczyło jeszcze czterech senatorów. Byli to kasztelanowie: sandomierski A. Łacki, wiślicki Tomasz Sołtyk, małogoski Paweł Popiel (ważna postać wśród sandomierskich regalistów ${ }^{111}$ ) i czechowski Stefan Dembowski. Marszałkiem koła rycerskiego został starosta nowokorczyński M. Rey. Pomagało mu sześciu asesorów (pisarz ziemski sandomierski S. Młodecki, starościc uściskowski Celestyn Gołuchowski, podsędek radomski M. Strasz, miecznik stężycki Stefan Chomentowski, chorążyc opoczyński A. Kazimierz

${ }^{104}$ Król do Z. Lubomirskiej z 16 XI 1782 i Z. Lubomirska do króla z 24 XI 1782, $\mathrm{BCz} 671$, s. 435-437.

${ }^{105}$ Król do J. Małachowskiego z 13 II 1783, BCz 673, s. 103.

106 J. Małachowski do króla z 1 III 1783, BCz 673, s. 109-110.

${ }^{107}$ Laudum sejmiku w Opatowie z 19-20 VIII 1782, BPAU 8341, s. 1062.

${ }^{108}$ K. Skotnicki do króla, bez daty (odebrany 8 VII 1783) i król do K. Skotnickiego z 10 VII 1783, BCz 689, s. 317, 319.

${ }^{109}$ M. Sołtyk do króla z 16 VII 1783, BCz 688, s. 185-186.

${ }^{110}$ Laudum sejmiku w Opatowie z 16 VII 1783, BPAU 8341, s. 1101-1102.

111 J. Michalski, Sejmiki poselskie 1788 r..., cz. 2, s. 346; E. Rostworowski, Popiel Paweł, [w:] PSB, t. XXVII, Wrocław 1973, s. 566. 
Skórkowski i regent grodzki nowokorczyński Franciszek Strzałkowski) ${ }^{112}$, więc reprezentujących wszystkie powiaty województwa $z$ wyjątkiem pilzneńskiego. Czwórkę kandydatów do podkomorstwa wybrano jednomyślnie. Zostali nimi: choraży radomski Wojciech Święcicki, chorąży opoczyński Jan Skórkowski, chorąży chęciński A. Dobiecki i wojski większy sandomierski Kazimierz Karski. Tym razem żadnego $z$ pretendentów w szczególny sposób nie wyróżniono ${ }^{113}$. Na uwage zasługują trzy osoby, które wkrótce wykazały się dużą aktywnością na arenie parlamentarnej. Asesor sejmiku K. Skórkowski, poseł na Sejm Wielki, był w czasie jego obrad czołowa postacią antykonstytucyjnej opozycji w Sandomierskiem $^{114}$. Kolejny asesor F. Strzałkowski i kandydat do podkomorstwa K. Karski jako posłowie sandomierscy aktywnie uczestniczyli w sejmie $z 1786$ r. ${ }^{115}$ Obrady miały uroczysta oprawę, gdyż marszałek zgromadzenia M. Rey ofiarował województwu kosztowną laskę, która jego pradziad (Władysław Rey ${ }^{116}$ ) otrzymał od Ludwiki Marii. Laska miała w przyszłości służyć kolejnym marszałkom sejmikowym, a przechowywać ją miano w skarbcu kolegiaty opatowskiej, która wyznaczona została na miejsce sejmikowania „na zawsze”, jak czytamy w uchwale ${ }^{117}$.

Stanisław August nie wrócił do sprawy podziału podkomorstwa sandomierskiego w następnych latach. Istotnym czynnikiem, oprócz rzecz jasna braku podstaw ustawowych dla reformy, było stanowisko posłów sandomierskich na sejmie z $1782 \mathrm{r}$. wobec opozycyjnego projektu posła lubelskiego Stanisława Kostki Potockiego, związanego ze sprawa ubezwłasnowolnienia przez kapitułę krakowską ( $z$ użyciem pomocy wojskowej udzielonej przez Departament

${ }^{112}$ Laudum sejmiku w Opatowie z 16 VII 1783, BPAU 8341, s. 1103-1106 i 1110-1112; Z. Anusik, Strasz Michał..., s. 210.

${ }^{113}$ Laudum sejmiku w Opatowie $z 16$ VII 1783, BPAU 8341, s. 1106-1107.

114 W. Szczygielski, Referendum trzeciomajowe..., s. 189-191. Na temat roli Skórkowskiego w obronie zasady elekcyjności tronu por. Z. Zielińska, „O sukcesyi tronu $w$ Polszcze" 1787-1790, Warszawa 1991, s. 167; A. Grześ kowiak-Krwa- w i c z, Skórkowski Albin Kazimierz, [w:] PSB, t. XXXVIII, Warszawa-Kraków 1997-1998.

115 A. Danilczyk, Strzałkowski Franciszek, [w:] PSB, t. XLIV, s. 574; id em, W kregu afery..., s. 150, 152, 156, 161; R.W. Wołoszyński, Karski Kazimierz, [w:] PSB, t. XII, Wrocław 1966, s. 131; W. Filipczak, Rugi i losy "rozdwojonych" sejmików przedsejmowych 1778-1786, „Czasopismo Prawno-Historyczne” 1997, t. XLIX, z. 1-2, s. 83-84.

$116 \mathrm{Na}$ temat roli W. Reya na dworze Ludwiki Marii por. S. Ochmann- Stan is zew ska, Dynastia Wazów w Polsce, Warszawa 2006, s. 272.

${ }^{117}$ Laudum sejmiku w Opatowie z 16 VII 1783, BPAU 8341, s. 1107-1109. 
Wojskowy Rady) biskupa Kajetana Sołtyka ${ }^{118}$. Większość reprezentantów sejmiku opatowskiego poparła w jawnych głosowaniach propozycję zgłoszona przez przeciwników stronnictwa dworskiego (w sześciu jawnych głosowaniach za kolejnymi punktami projektu opowiadało się czterech na siedmiu posłów sandomierskich) ${ }^{119}$.

Omówione starania o ziemskie urzędy sądowe w województwie sandomierskim potwierdzaja opinię szambelana Anastazego Walewskiego o roli urzędów sądowych dla organizacji zaplecza sejmikowego dworu. Anastazy Walewski uważał, że są dwa sposoby realizowania interesów królewskich w województwie. Pierwszym było obsadzanie zaufanymi ludźmi ziemstw i grodów, gdyż te jurysdykcje „najwięcej pomagają i wspierają kredyt, bo utrzymuja przyjaciół, mając ich zawsze pod swoim sądem, utrzymuja spokojność wewnętrzna $z$ powagi swojej i mając moc ich karania" (drugi sposób to „forsa”) ${ }^{120}$. Sprawa kreowania dwóch nowych podkomorstw $\mathrm{w}$ województwie sandomierskim wskazuje również, że w podejmowaniu decyzji dotyczacych organizacji sądownictwa szlacheckiego względy polityczne mogły odgrywać bardzo istotną rolę.

W praktyce sejmików elekcyjnych województwa sandomierskiego $z$ lat 1777-1783 na szczególną uwage zasługuje zwyczaj rekomendowania jednego $z$ czwórki kandydatów (niekoniecznie pierwszego na liście). Zjawisko to występowało jedynie na sejmikach powiatów sandomierskich w Opatowie, nie miało zaś miejsca w czasie obrad w Radomiu (w 1781 r.) i na zgromadzeniu całego województwa w Opatowie (w 1783 r.). W czasach Rady Nieustającej jednoznaczne polecanie względom monarchy jednego $z$ kandydatów należało w Koronie do rzadkości. Poza województwem sandomierskim sytuację taka można było czasami spotkać także na sejmikach chełmskich oraz lubelskich ${ }^{121}$. Trudno ocenić, czy istniał tu

118 W. Filipczak, Życie sejmikowe..., s. 96-97. Por. też A. Stroynowski, Opozycja sejmowa $w$ dobie rzadów Rady Nieustajacej. Studium $z$ dziejów kultury politycznej, Łódź 2005, s. 163-164.

119 Tabele jawnych głosowań w izbie poselskiej, AGAD, ZP 108, k. 29v, 33v, $46 \mathrm{v}, 50 \mathrm{v}, 81 \mathrm{v}, 85 \mathrm{v}$.

120 A. Walewski do króla, bez daty [1783], $\mathrm{BCz}$ 932, s. 229; B. Zaleski, Korespondencja krajowa Stanisława Augusta z lat 1784 do 1792, Poznań 1872, s. 41; M. Kobierecki, op. cit., s. 123.

${ }^{121}$ Lauda sejmików w Chełmie z 16 VII 1782 i 5 XI 1782, Archiwum Państwowe w Lublinie [dalej: APL], Chełmskie grodzkie rmo, sygn. 91 - akta luźne, k. 23-23v, 295-295v; Laudum sejmiku w Lublinie z 3 II 1778, APL, Lubelskie grodzkie rmo, sygn. 434 , k. 508-508v. 
związek $z$ oddziaływaniem wzorów litewskich na sejmiki koronne. Jak pisałem, w XVII w. pojawiła się praktyka, że sejmiki litewskie wybierały wprawdzie czterech kandydatów na urzędy, lecz czasami trzech $z$ nich rezygnowało $z$ ubiegania się o godność. Od $1764 \mathrm{r}$. litewskie sejmiki elekcyjne miały wybierać już nie czterech kandydatów, ale jednego, który musiał uzyskać wprawdzie przywilej królewski, jednak podejmował obowiazki sądowe już po elekcji i złożeniu odpowiedniej przysięgi ${ }^{122}$. W odniesieniu do Korony sejmikowe rekomendacje nie były dla monarchy wiążące. W województwie sandomierskim Stanisław August je uwzględniał, co miało związek $z$ dominacją regalistów w życiu sejmikowym.

\section{Bibliografia}

\section{ŹRÓDEA DRUKOWANE}

Dyaryusz Seymu wolnego ordynaryinego warszawskiego... 1780.., wyd. S. Badeni, Warszawa [1780].

„Ksiega domowa” Leona i Hieronima Kochanowskich 1763-1855, „Przegląd Historyczny" 1916, t. XX, z. 1.

Volumina Legum, t. II, VII-VIII, wyd. J. Ohryzko, Petersburg 1859-1860.

Zaleski B., Korespondencja krajowa Stanisława Augusta z lat 1784 do 1792, Poznań 1872.

\section{OpRacowania}

Achremczyk S., Reprezentacja stanowa Prus Królewskich w latach 1696-1772, Olsztyn 1981.

Anusik Z., Strasz Michat, [w:] Polski słownik biograficzny, t. XLIV, Warszawa-Kraków 2006-2007, s. 210-213.

Błaszczyk G., Litwa na przełomie średniowiecza i nowożytności 1491-1569, Poznań 2002.

Buben V., Rozdwojone wybory urzędników ziemskich na sejmiku elekcyjnym województwa nowogródzkiego 5 lutego 1777 roku, „Zeszyty Naukowe Uniwersytetu Jagiellońskiego. Prace Historyczne” 2006, z. 133, s. 55-71.

Chojecki R., Patriotyczna opozycja na sejmie 1773 r., „Przeglad Historyczny” 1972, R. LXXIX, s. 545-561.

Cywiński R., Sołtyk Maciej, [w:] Polski słownik biograficzny, t. XL, Warszawa-Kraków 2001, s. 410-412.

Danilczyk A., W kręgu afery Dogrumowej. Sejm 1786 roku, Warszawa 2010.

${ }^{122}$ A.B. Zakrzewski, Sejmiki Wielkiego Księstwa Litewskiego XVI-XVIII w..., s. $162-165$. 
Danilczyk A., Strzałkowski Franciszek, [w:] Polski słownik biograficzny, t. XLIV, Warszawa-Kraków 2006-2007, s. 573-574.

Filipczak W., Rugi i losy „rozdwojonych” sejmików przedsejmowych 1778-1786, „Czasopismo Prawno-Historyczne” 1997, t. XLIX, z. 1-2, s. 65-85.

Filipczak W., Sejm 1778 roku, Warszawa 2000.

Filipczak W., Sejmiki województwa płockiego 1780-1786, „Przegląd Nauk Historycznych" 2009, R. VIII, nr 2, s. 23-62.

Filipczak W., Sejmiki ziemi czerskiej 1780-1786, „Przegląd Nauk Historycznych” 2010, R. IX, nr 1, s. 139-179.

Filipczak W., Życie sejmikowe prowincji wielkopolskiej w latach 1780-1786, Łódź 2012.

Grześkowiak-Krwawicz A., Skórkowski Albin Kazimierz, [w:] Polski słownik biograficzny, t, XXXVIII, Warszawa-Kraków 1997-1998, s. 348-349.

Kobierecki M., Walewscy herbu Kolumna w XVII-XVIII wieku. Genealogia. Majętności. Działalność publiczna, Łódź 2008.

Konieczna D., Ustrój i funkcjonowanie sejmików elekcyjnych $w$ powiecie brzesko-litewskim do 1764 roku, [w:] Po unii-sejmiki szlacheckie w Rzeczypospolitej XVI-XVIII wieku, red. H. Lulewicz, M. Wagner, Siedlce 2013, s 43-57.

Kriegseisen W., Samorzad szlachecki $w$ Małopolsce $w$ latach 1669-1717, Warszawa 1989.

Kriegseisen W., Sejm Rzeczypospolitej szlacheckiej (do 1763 roku), Warszawa 1995.

Lityński A., Sejmiki województwa płockiego przed i w czasie Sejmu Czteroletniego. $Z$ badań nad organizacja i funkcjonowaniem, [w:] W dwusetna rocznice wolnego Sejmu. Ludzie - państwo - prawo czasów Sejmu Czteroletniego, red. A. Lityński, Katowice 1988, s. 76-108.

Lityński A., Sejmiki ziemskie 1764-1793. Dzieje reformy, Katowice 1988.

Michalski J., Lubomirski Stanisław, [w:] Polski słownik biograficzny, t. XVIII, Wrocław 1973, s. 53-56.

Michalski J., Ogrodzki Jacek, [w:] Polski słownik biograficzny, t. XXIII, Wrocław 1978, s. 648-651.

Michalski J., Reforma sądownictwa na sejmie konwokacyjnym 1764 roku, [w:] Między wielka polityka a szlacheckim partykularzem. Studia z dziejów nowożytnej Polski i Europy ku czci Profesora Jacka Staszewskiego, Torun 1993, s. 295-313.

Michalski J., Sejm w czasach panowania Stanisława Augusta, [w:] Historia sejmu polskiego, red. J. Michalski, Warszawa 1984.

Michalski J., Sejmiki poselskie 1788 r., cz. 1, „Przegląd Historyczny” 1960, t. LI, z. 1 , s. $52-73$.

Michalski J., Sejmiki poselskie 1788 r., cz. 2, „Przegląd Historyczny” 1960, t. LI, z. 2, s. 331-365.

Moniuszko A., Mazowieckie sady ziemskie (1588-1648). Organizacja-funkcjonowanie - postepowanie, Warszawa 2013.

Ochmann-Staniszewska S., Dynastia Wazów w Polsce, Warszawa 2006.

Olszewski P., Kanclerz Jacek Nałęc Małachowski (1737-1821), Kielce 2013. 
Pielas J., Szlachta sandomierska wobec najważniejszych wydarzeń politycznych pierwszych lat panowania Augusta II (1696-1704), [w:] Rzeczpospolita $w$ dobie wielkiej wojny północnej, red. J. Muszyńska, Kielce 2001, s. 127-148.

Rachuba A., Wielkie Ksiestwo Litewskie w systemie parlamentarnym Rzeczypospolitej w latach 1569-1763, Warszawa 2002.

Rolnik D., Sejmiki poselskie drugiej połowy panowania Stanisława Augusta. O czynnikach i motywacjach decydujacych o wyborze posłów sejmowych, [w:] Po unii-sejmiki szlacheckie w Rzeczypospolitej XVI-XVIII wieku, red. H. Lulewicz, M. Wagner, Siedlce 2013, s. 331-355.

Rostworowski E., Ostatni król Rzeczypospolitej. Geneza i upadek Konstytucji 3 Maja, Warszawa 1966.

Rostworowski E., Głębocki Karol, [w:] Polski słownik biograficzny, t. VIII, Wrocław 1959, s. 110.

Rostworowski E., Popiel Pawet, [w:] Polski słownik biograficzny, t. XXVII, Wrocław 1973, s. 565-568.

Rymszyna M., Gabinet Stanisława Augusta, Warszawa 1962.

Serczyk W., Kicki Jan, [w:] Polski słownik biograficzny, t. XII, Wrocław-Warszawa-Kraków 1966-1967, s. 388-389.

Sokalski M., Między królewskim majestatem a szlachecka wolnościa. Postawy polityczne szlachty małopolskiej w czasach Michała Korybuta Wiśniowieckiego, Kraków 2002.

Stanek W., Konfederacja sejmowa z 1776 roku - narzedzie dworskiego zamachu stanu, „Acta Universitatis Nicolai Copernici”, Historia 28, 1993, s. 135-147.

Stroynowski A., Opozycja sejmowa $w$ dobie rzadów Rady Nieustającej. Studium z dziejów kultury politycznej, Łódź 2005.

Swieżawski A., Rawskie Księstwo Piastów Mazowieckich 1313-1462. Dzieje polityczne, Łódź 1975.

Szczygielski W., Olizar Franciszek Kajetan, [w:] Polski słownik biograficzny, t. XXIII, Wrocław 1978, s. 812-813.

Szczygielski W., Potkański Antoni, [w:] Polski słownik biograficzny, t. XXVII, Wroclaw 1983, s. 721.

Szczygielski W., Referendum trzeciomajowe. Sejmiki lutowe 1792 roku, Łódź 1994.

Trawicka Z., Sejmiki województwa sandomierskiego w latach 1572-1696, Kielce 1985.

Trawicka Z., Życie polityczne szlachty województwa sandomierskiego $w$ drugiej połowie XVII w., [w:] Między monarcha a demokracją. Studia z dziejów Polski XV-XVIII wieku, red. A. Sucheni-Grabowska, A. Żaryn, Warszawa 1994, s. 270-313.

Urzędnicy województwa sandomierskiego XVI-XVIII wieku. Spisy, oprac. K. Chłapowski i A. Falniowska-Gradowska, red. A. Gąsiorowski, Kórnik 1993.

Wisner H., Rzeczpospolita Wazów, cz. 3 (Sławne Państwo Wielkie Księstwo Litewskie), Warszawa 2008.

Województwo sandomierskie $w$ drugiej połowie XVI wieku, red. W. Pałucki, cz. 2, Warszawa 1993. 
Wołoszyński R.W., Karski Kazimierz, [w:] Polski słownik biograficzny, t. XII, Wrocław 1966, s. 131.

Zakrzewski A.B., Sejmiki Wielkiego Księstwa Litewskiego XVI-XVIII w. Ustrój i funkcjonowanie: sejmik trocki, Warszawa 2000.

Zakrzewski A.B., Sejmiki Wielkiego Księstwa Litewskiego epoki stanisławowskiej (do 1788 r.). Zmiany w ustroju i funkcjonowaniu, [w:] Ziemie północne Rzeczypospolitej polsko-litewskiej $w$ dobie rozbiorowej 1772-1815, red. M. Biskup, Warszawa-Torun 1996, s. 59-66.

Zakrzewski A.B., Wielkie Księstwo Litewskie (XVI-XVIII w.). Prawo, ustrój, społeczeństwo, Warszawa 2013.

Zielińska Z., Poniatowski Michał Jerzy, [w:] Polski słownik biograficzny, t. XXVII, Wrocław 1983, s. 455-471.

Zielińska Z., „O sukcesyi tronu w Polszcze” 1787-1790, Warszawa 1991.

Żerek-Kleszcz H., Posłowie łęczyccy 1764-1792 i ich status majątkowy, „Acta Universitatis Lodziensis", Folia historica 72, 2001, s. 133-146.

Witold FiLIPCZAK

\title{
Provincial judiciary in political life of the Sandomierz Voivodship in the years 1777-1783
}

\begin{abstract}
AT the beginning of the article the author draws attention to the legal aspects connected with the election of candidates who would hold judicial offices, and the changes taking place in this process from the $16^{\text {th }}$ till the $18^{\text {th }} \mathrm{c}$. In the years 1777-1783 there were three district judicial offices, six offices that bore the name starostwo grodowe, and only one office of succamerarius in Sandomierz Voivodeship. In the period under discussion seven sejmiks that gathered in Opatow and one that gathered in Radom chose candidates for the judicial offices of Sandomierz and Radom. In 1783 the sejmiks in Stężyca (for Stężyca district) were probably held three times, but their resolutions are not known. The article discusses preparations for particular sejmiks, their course and decisions that were made. In the years 1777-1778 decisions of two sejmiks that took place in Opatów were questionable from the legal point of view. It was connected with the fact that the judicial office held by a districts' judge of Sandomierz was regarded as vacated. After the first partition of Poland its holder's estates found themselves outside the boundary of the voivodeship which was now smaller. Besides, he acted as a judge in the territory occupied by Austria. In 1782 a project approved by the king came into being; it stated that three offices of succamerarius should be established instead of one. The turbulent sejm of 1782 made it impossible to pass the bill on that matter. The following year the king gave up his proposal, which may have been caused by the attitude of the majority of the envoys from Sandomierz Voivodeship during the recent sejm. In compliance with the king's recommendation candidates for the position of succamerarius of the whole voivodeship were elected in Opatów in 1783.
\end{abstract}

Keywords: Sandomierz Voivodeship, district judicial offices, sejmiks, parliamentarism. 